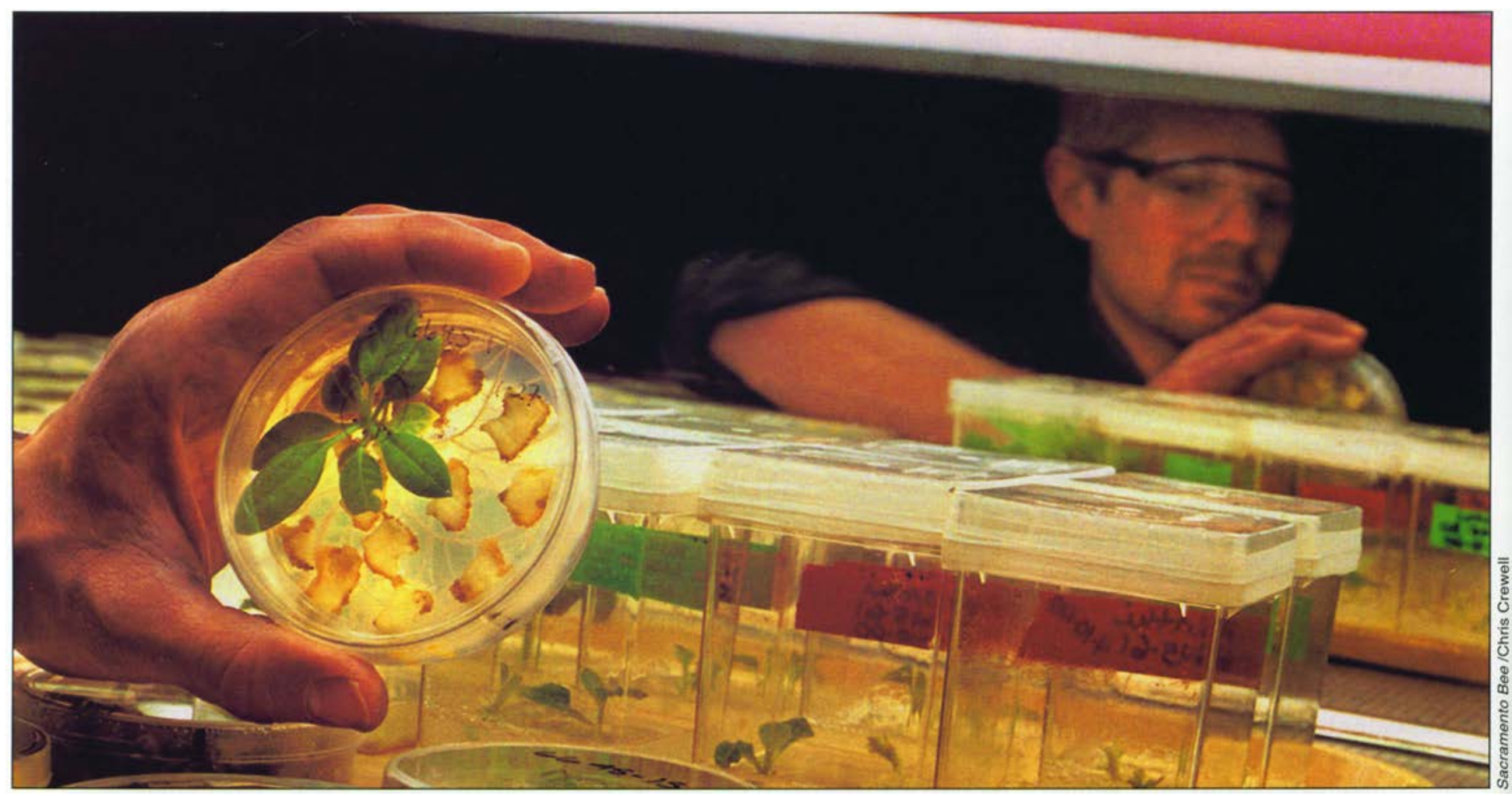

Industry-university collaboration has become increasingly common. In 1980, UC Davis faculty formed Calgene; after conflict-ofinterest issues were raised, UC began requiring that professors disclose financial ties with private firms. Calgene senior researcher Eric Aasen holds plant tissue that has been bombarded with DNA genes from human milk, for research on reducing hypertension.

\title{
Commercialization of university research brings benefits, raises issues and concerns
}

\section{William B. Lacy}

New commercial opportunities, patent laws and federal policies, as well as growth in private-sector research and a relative decline in public-sector funding for agricultural research, have contributed to a changing collaborative relationship between universities and industries. While such partnerships have existed for decades, these new relationships, particularly in agricultural biotechnology, are generally more varied, wider in scope, more aggressive and experimental, and more publicly visible. Examples of UC-industry collaborations include Calgene at UC Davis, Ceres, Inc. at UCLA, and the Novartis alliance at UC Berkeley. On the benefits side, such collaboration may bring useful products to market, promote U.S. technological leadership in the world economy and provide funding and "hands-on" opportunities for students. However, concerns have arisen that such collaborations may narrowly redirect research agendas, disrupt long-term research and create conflicts of interest. For these collaborations to be mutually beneficial, the potential negative consequences must be monitored and addressed aggressively with appropriate policies, practices and organizational arrangements. At the same time, adequate investment for public-sector research will be essential for universities to be a strong and complementary partner.
Qince passage of the Hatch Act in 1887 , U.S. public-sector agricultural research has focused on both basic and applied science in agriculture, then the primary industry in the country.

Land-grant university scientists have employed multiple approaches to enhance agricultural productivity and improve the quality of life for rural America.

Historically, land-grant universities developed relationships with the private sector, including working closely with producers and commodity groups, the seed, fertilizer and agricultural chemical industries, machinery manufacturers and food-processing companies: These relationships constituted a very small portion of the research agenda, often involving individual scientists in the testing of seeds, chemicals, equipment or new pro- 
cesses in exchange for modest support of some portion of their research agenda. They generally occurred within the context of ensuring open and unfettered communication among faculty and scientists. The vast majority of financial support for public-sector agricultural research, however, has come from a combination of state and federal noncompetitive funding.

\section{Scientific and societal changes}

During the last 20 years, however, significant changes have occurred in the way universities conduct agricultural science and generate and commercialize knowledge, as new institutional arrangements and public and private research partnerships have evolved.

Globalization. Since the 1980 s, debt crises in numerous nations and rapid globalization of the economy have been coupled with a decline in the relative importance of national economics. Globalization is the integration of capital, technology and information across national boundaries in a way that creates a single global market. It includes the proliferation of international commodity chains, as well as transnational firm expansions and corporate mergers. International trade agreements such as North American Free Trade Agreement, and General Agreement on Trade and Tariffs, World Trade Organization and the European Union have facilitated the creation of global markets, including those for agricultural commodities and technology. Public and private-sector knowledge generation and commercialization take place in this new context.

Scientific advances. At the same time, equally dramatic changes have occurred in science. New scientific techniques and tools have facilitated efforts to understand the complex functioning of living organisms at the molecular and cellular levels and accelerated the accumulation of knowledge in traditional disciplines such as biology, genetics, plant physiology and biochemistry. Application of this knowledge is truncating both the time and space required to develop new plant, animal and food products. It may also complement and extend tra- ditional methods used to enhance agricultural productivity, environmental stewardship and nutritional quality. The New York Times recently noted that with the advent of biotechnology, agriculture is entering the Information Age with a small number of multinational corporations positioned to become its "Microsoft," supplying the proprietary operating systems to run the new generation of plants and animals (Pollan 1998).

Biotechnology. A rapid proliferation of new commercial biotechnology companies, starting with the founding of Genentech in 1976, paralleled these trends in the global economy and in science. While most biotechnology companies pursue applications in pharmaceuticals and diagnostics, a large number are also involved in agricultural biotechnology. By 1998, approximately one-quarter of more than 3,500 worldwide and approximately 1,500 U.S. companies were involved in some form of food and agriculture (Genetic Engineering News 1998). These companies are precisely the ones most likely to invest in research and pursue university linkages. In fact, the average biotechnology company expends about 10 times more per employee on research than the U.S. average, with industrial leaders expending substantially more (Murashige 1997).

Legal developments. In the United States, a series of landmark patent decisions, starting in 1980 with the U.S. Supreme Court decision Diamond v. Chakrabarty (447 U.S. 303), provided complete patent protection for genetically engineered life forms
In 1998, UC Berkeley's College of Natural Re sources announced a $\$ 25$ million research alliance with the Swiss biotechnology giant Novartis. At the USDA Plant Gene Expression Center in Albany, UC Berkeley scientist Peggy Lemaux and postdoctoral student Yuechun Wan conducted genetic engineering research on cereal crops to improve the food and feed characteristics of grain.

from microorganisms to plants and animals. With their potential for rapid development of a spectrum of new proprietary products, the new biotechnologies have markedly increased corporate interest in patenting, particularly the creation of strong and internationally uniform patent laws to protect their investments (Murashige 1997).

Patents and licensing. U.S. universities have become major players in filing for patents and licensing their protected processes and inventions. In 1974 , a total of only 177 patents were awarded to the top 100 research uni- 
The new types of universityindustry relationships, particularly in agricultural biotechnology, are generally more varied, wider in scope, more aggressive and experimental, and more publicly visible than the relationships of the past.

versities. By 1998, the top 132 U.S. research universities were awarded 2,681 new U.S. patents, and earned over $\$ 576$ million in royalties from approximately 5,000 income-producing licenses (Blumenstyk 1999). As in past years, UC was the top earner with $\$ 73$ million in royalties and more than 500 income-producing licenses (table 1).

Of the 3,328 licenses and options executed by universities in 1997, about three-fifths went to small businesses and startup companies (with fewer than 500 employees). Further, about half of these licenses and options gave a company the exclusive rights to a process or invention. Nearly twothirds of the licenses and options were for inventions related to drugs, medical devices and other life-science products. Finally, these universities formed 258 startup companies based on technology they developed and licensed to the new businesses (Cohen et al. 1998; Blumenstyk 1999).

New laws. During the 1980s, Congress passed several new laws de- signed to bring more technology to the marketplace, encourage research institutions to patent discoveries made in the course of government-sponsored research and offer licenses to the private sector. The Bayh-Dole Act of 1980 enabled universities to patent inventions resulting from research that received federal support (Press and Washburn 2000). As a result, involvement of industry in university research has jumped dramatically. A few years later, the Federal Technology Transfer Act of 1986 and the Executive Order of April 10, 1987, required government research agencies engaged in extensive biotechnology work such as the National Institutes of Health (NIH) and U.S. Department of Agriculture (USDA) to establish close collaborations with private companies (Busch et al. 1991).

Federal funding increases. During this same period, the federal government and private sector directed substantial support to research and development within the United States. In 1999 total support for research and development was estimated at nearly $\$ 250$ billion, approximately $\$ 70$ billion from the federal government and about $\$ 166$ billion from industrial firms (the private sector) (Broad 1999). For university research, the federal government still represents a major funding source, providing an estimated $60 \%$ of research and development dollars in 1997, down from about $68 \%$ in 1980 and $71 \%$ in 1970 . California particularly benefits from federal funds, receiving $20 \%$ of all federal research dollars (Los Angeles Times, Jan. 21,2000 ).

\begin{tabular}{lccr}
\multicolumn{4}{c}{ TABLE 1. Top 10 royalty-producing U.S. universities, fiscal 1998 } \\
\hline \hline Institution & $\begin{array}{c}\text { License } \\
\text { revenue }\end{array}$ & $\begin{array}{c}\text { Licenses } \\
\text { held }\end{array}$ & $\begin{array}{r}\text { Start-up } \\
\text { companies } \\
\text { founded }\end{array}$ \\
\hline & $\$$ & $n 0$. & $n$. \\
University of California & $73,101,000$ & 696 & 19 \\
Columbia University & $61,649,002$ & 245 & 5 \\
Florida State University & $46,642,688$ & 10 & 2 \\
Stanford University & $43,197,379$ & 299 & 6 \\
Yale University & $33,261,248$ & 84 & 5 \\
Carnegie Mellon University & $30,065,000$ & 20 & 1 \\
Michigan State University & $24,336,872$ & 41 & 8 \\
University of Washington, Washington Research Foundation & $21,299,214$ & 204 & 4 \\
University of Florida & $19,144,753$ & 55 & 19 \\
Massachusetts Institute of Technology & $18,046,991$ & 267 & \\
\hline Source: Blumenstyk 1999. & & & \\
\end{tabular}

Recently, congressional leaders and the White House announced strong support for increasing science funding over the next several years. The President's fiscal year 2001 budget proposed a nearly $\$ 3$ billion increase in spending on science and technology (Los Angeles Times, Jan. 21, 2000). Regardless, the major research universities have not actually increased their share of federally funded research during the past two decades. Instead, a larger number of universities and colleges - particularly nonresearch and non-doctorate-granting institutions - are now receiving federal support. As a result, federal support per academic researcher has declined $9.4 \%$ in real terms (Cohen et al. 1998).

Private-sector spending. From 1994 to 1999 , U.S. industrial research and development grew from $\$ 97.1$ billion to $\$ 166$ billion, a rise of $71 \%$ and more than double the federal government's spending. From 1980 to 1997, industry support for research and development at U.S. academic institutions grew an estimated $8.1 \%$ annually in constant dollars, more rapidly than support from all other sources. As a consequence, industry support for university research has grown from $2.6 \%$ in 1970 to approximately $7.0 \%$ today as a percentage of total academic research (approximately $\$ 2.2$ billion) (NSF 1998). At UC Davis, industry's share of total funding for research contracts and grants rose from $9.9 \%$ in 1989 , to $11 \%$ in 1998 and 15\% in 1999 (Wright 2000).

Agricultural research funding. This growth in overall research funding is in sharp contrast to the public funding available to the food and agriculture research community. Historically a major source of federal funds for food and agriculture research, USDA provided only $2 \%$ of the total federal support for research and development in fiscal year 1998 (Korzumi and Nelson 1997). In fact for the last two decades, university agricultural research and extension appropriations have received little or no increase after inflation with total annual USDA research appropriations at about $\$ 400$ million and total USDA extension appropriations at about $\$ 425$ million. This is particularly true for 
base funds provided through federal USDA Hatch and Smith-Lever appropriations for research and extension, respectively.

Bolstered by several National Research Council (NRC 1996, 1994, 1989) reports and external analyses of the system (Weaver 1993; Meyer 1995), the food and agriculture public-sector research and education community has attempted to initiate new and expanded competitive federal research programs, including the National Research Initiative, the Sustainable Agriculture Research and Education Program, the Fund for Rural America and, most recently, the new Initiative for Future Agriculture and Food Systems. To date such efforts have failed to mobilize sufficient USDA and congressional support, and only modest new funding and resources have become available.

\section{Public-private collaboration}

The new commercial opportunities, patent laws and federal policies, as well as growth in private-sector research and a relative decline in publicsector funding for agricultural research, have all contributed to a changing collaborative relationship between universities and industries. While partnerships have existed for several decades, the new types of university-industry relationships, particularly in agricultural biotechnology, are generally more varied, wider in scope, more aggressive and experimental, and more publicly visible than the relationships of the past.

The legal/contractual bases for these relationships depend on the goals and institutional characteristics of the partners, and as a consequence involve diverse approaches. These may include:

- Large grants and contracts between companies and universities in exchange for patent rights and exclusive licenses to discoveries;

- Programs and centers organized with industrial funds at major universities - now totaling well over 1,000 (Lee 1998) - that give participating private firms privileged access to university re-

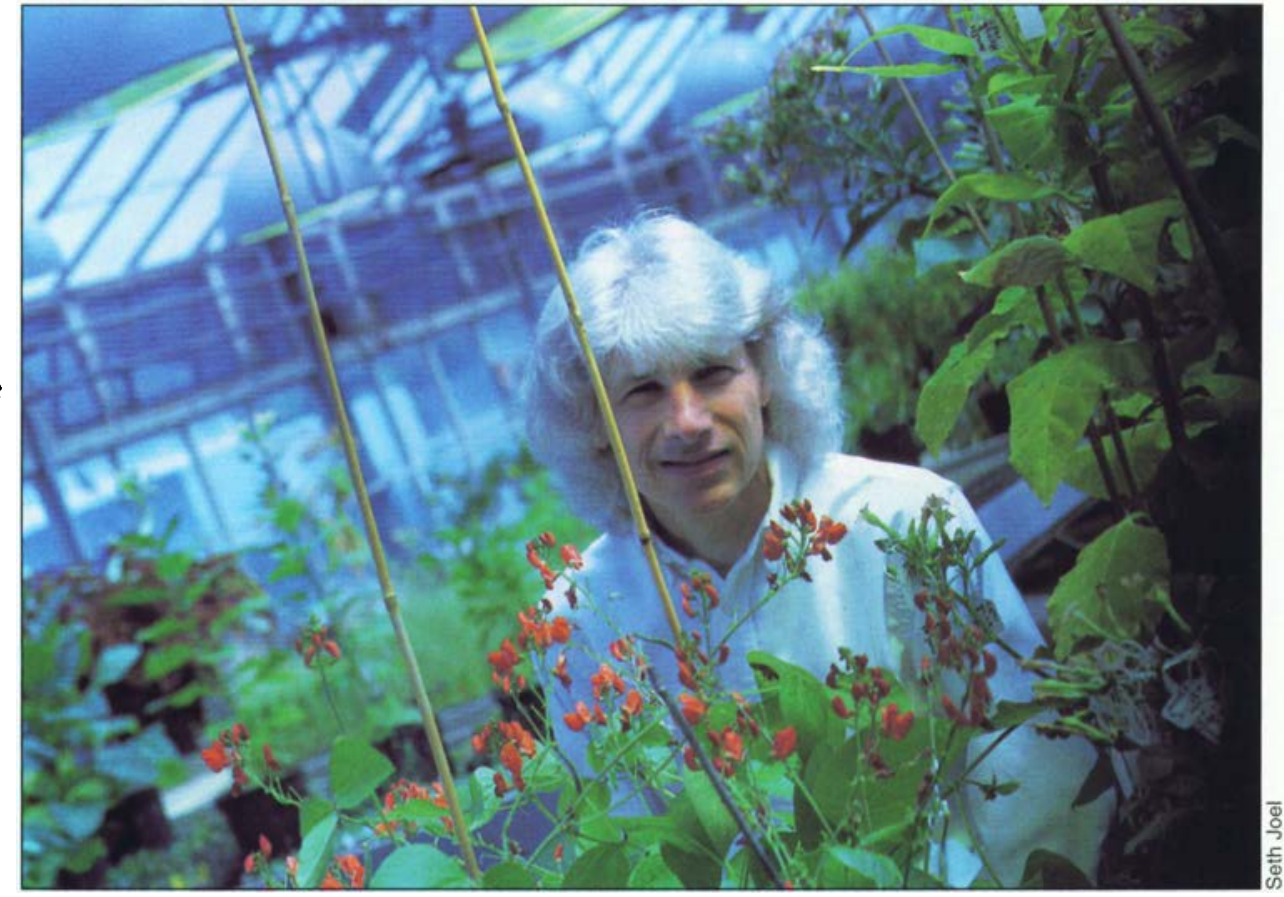

UCLA professor Robert B. Goldberg is co-director of the Seed Institute, a partnership between UC and Ceres, Inc. The agricultural biotechnology company will spend $\$ 5.75$ million over 5 years to support plant molecular biology research at the institute as well as a Plant Genomics Technology Center.

sources and a role in shaping research agendas;

- Professors, particularly in the biomedical sciences, serving in consulting capacities on scientific advisory boards or in managerial positions in the firms;

- Faculty receiving research funds from private corporations in which they hold equity; and

- Public universities establishing business startups and for-profit corporations to develop and market innovations arising from research. (The Chronicle of Higher Education reported that the top 92 U.S. universities in licensing income for fiscal year 1998 also indicated they had formed 279 startup companies [Blumenstyk 1999]).

California has been a leader in the establishment of a variety of university-industry research collaborations. UC President Richard Atkinson has described industry partnerships as "an essential aspect of both our intellectual endeavor and our research base" (Wright 2000). Atkinson supported a 1996 increase in the state tax credit from $12 \%$ to $24 \%$ for business investment in university research. At the same time, he created the IndustryUniversity Cooperative Research Program of matching grants for research in economic sectors of significant commercial promise, such as biotechnology and semiconductor manufacturing. Most recently, California Governor Gray Davis unveiled a plan to spend $\$ 75$ million in 2001 on three new institutes for science and innovation on UC campuses, which will require $\$ 150$ million from nonstate funds, presumably industrial partners (Wright 2000).

Specific examples of such universityindustry collaborations include a number of instances in which faculty have started their own companies. In 1980, UC Davis faculty formed Calgene, an agricultural biotechnology firm (now owned by Monsanto), which aggressively established close links to the private sector. As a result of concerns about conflicts of interest, the chief executive officer, a faculty member, was forced to cut some financial ties with the company. The UC conflict-of-interest code was revised, and the state began requiring UC professors to disclose financial ties with private firms (Wright 2000).

At UCLA, Ceres, Inc., an agricultural biotechnology company co- 


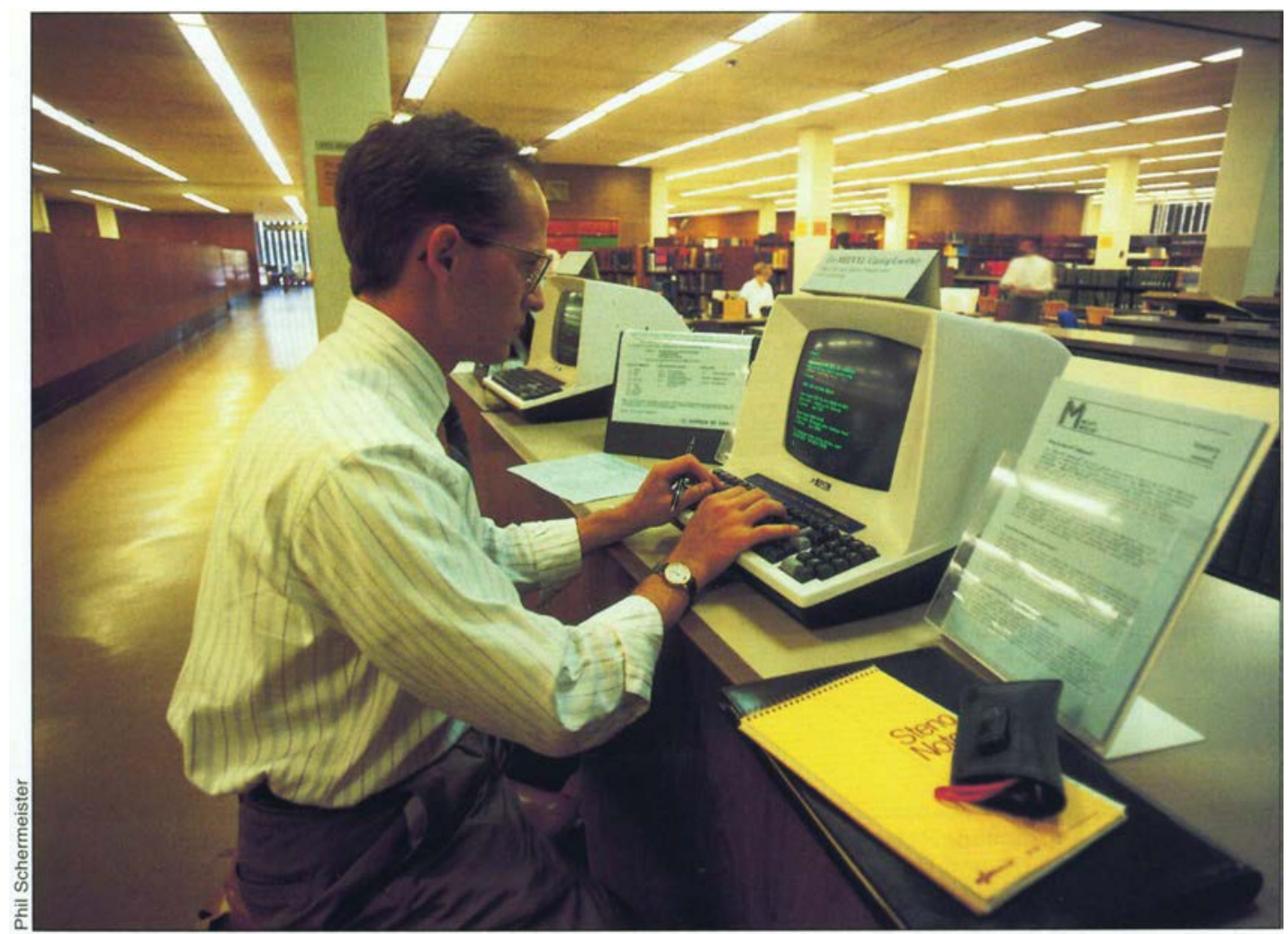

New commercial opportunities, patent laws and federal policies, as well as the growth in private-sector research and decline in publicly funded agricultural research, have contributed to the changing relationship between universities and industry. Computer research is conducted at the UCLA library.

founded by a UCLA professor, gave the university $\$ 4.75$ million to support a new UC-based program called the Seed Institute, $\$ 1$ million to establish a Plant Genomics Technology Center at UCLA, and access to its genetic database and resources. In exchange, the company received the right of first refusal to license inventions arising from the research it supports (Wright 2000).

Another notable example of these new types of collaborative arrangements between universities and industry is the 5-year, $\$ 25$ million "strategic" research alliance announced in late 1998 between UC Berkeley's College of Natural Resources and a unit of the Swiss biotechnology giant Novartis (created in 1996 by the merger of CibaGeigy and Sandoz). While large, multimillion-dollar industry grants to universities are not unheard of, this agreement applies not to a single researcher or team focusing on a specific topic, but rather to the entire department of plant and microbial biology. Under the agreement, the Novartis unit will provide funds and access to proprietary technology to UC Berkeley faculty members and graduate stu- dents. In return, it will receive first rights to negotiate licenses for up to one-third of the inventions that result. Novartis is also considering the development of a facility on or near the Berkeley campus for 20 to 30 of its own scientists, who would be available to work with university researchers and share equipment and space

(Blumenstyk 1998a).

These new, more aggressive relationships between the university and the private sector are raising a number of issues regarding appropriate roles, goals and responsibilities. Many have noted that the university and the private sector are very different with respect both to their research goals, values and the ways they pursue them (Nelsen 1999).

\section{Potential benefits}

The outcomes of collaborations between two distinct and complementary research communities, public universities and private industry, can be both positive and negative.

Useful products. On the benefits side, university and industry collaboration may bring useful products such as improved seeds, plant protection products and diagnostic kits to market more rapidly and promote U.S. technological leadership in a changing world economy. This is a major motivation behind a number of recent federal laws and policy statements that require such collaboration as a condition for receiving federal research funds.

New research funding. In light of funding stagnation within USDA and in many cases at the state level, such collaborations are a means of raising new funds for university research, graduate education and postdoctoral fellowships. As noted above, industry support for university research has grown more rapidly than support from all other sources. Kevin Smith, UC Davis vice chancellor for research, observed that 1999 saw stunning growth in our research support from industry and the reason is that the faculty members are soliciting that support (Wright 2000).

Student benefits. Collaborations can introduce students to the industrial world and enhance their understanding of the nonacademic world of science. Moreover, these contacts can provide opportunities to explore career alternatives.

Access to technology. These joint efforts may expand the scientific network, increasing communication between industry and university scientists and providing some university scientists access to cutting-edge research tools, proprietary materials and vast databases. Companies began giving patents to universities several years ago, but the number and scale of these donations have increased substantially. For example, DuPont recently donated patents worth $\$ 64$ million to three U.S. public universities: Pennsylvania State University, University of Iowa and Virginia Tech. The universities are expected to invest their own resources to legally protect 
these proprietary technologies and knowledge and to conduct additional research and development that will subsequently be sold or licensed (Desruisseaux 2000).

Under the appropriate conditions, these relationships between public universities and the private sector can be highly beneficial. Gordon Rausser, dean of the UC Berkeley College of Natural Resources and key architect of the Novartis agreement, recently wrote: "We must focus on developing partnership structures where UC extracts the best from its industrial partners while safeguarding its values of academic freedom and peer oversight" (Rausser 1999).

\section{Possible negative consequences}

However, a number of issues and concerns have also been voiced regarding these new relationships.

Long-term research goals. Longterm research, previously a major emphasis of the public sector, may decline. The private sector generally has short-term proprietary goals, and as a consequence funding for research is often short term, spanning 1 or 2 years. A recent study reported that directed basic research (longer-term pursuits), while growing substantially in the 1990 s, still only constituted $6 \%$ of total private research and development (Broad 1999). In contrast, nearly all NIH extramurally funded programs and the USDA Hatch basefunded projects are for 3 years or longer, with renewals often possible, and USDA competitive grants are 2 to 3 years in duration.

Moreover, dependence on privatesector funds will generally change not only the time frame but also the stability of funding. It seems unlikely that university-industry relationships will provide stable, long-term funding nor will they significantly address the capital needs of universities.

Faculty concerns. Faculty perceptions parallel these figures about the time frame of private-sector research. In a recent national survey of U.S. faculty regarding concerns about close university-industry collaboration, academics were generally in favor of collaboration (Lee 1998). However, these same faculty expressed concerns and fears that such collaborations could affect academic freedom and shortand long-term research, and create conflicts of interest; $69 \%$ feared that collaboration is likely to generate pressure for more short-term research; and another $58 \%$ were concerned that collaboration is likely to disrupt their long-term basic research missions.

Research agendas. Universities are concerned about ensuring that research projects are generally originated by faculty members and not adopted as a result of outside pressure, either implicit or explicit. If a sufficiently large and influential number of academic scientists and engineers become involved with industry, a whole range of research agendas, traditionally the purview of the university community, might be de-emphasized. The UC Berkeley/Novartis collaboration raised these concerns. UC Berkeley Academic Senate Vice Chair Robert S. Spear noted that one of the "broader and more subtle impacts" of the agreement was "the potential for an unhealthy narrowing of the nature and direction of the department's research agenda, including the range of opportunities for graduate students" (Blumenstyk 1998a). Furthermore, the scientific community could become desensitized to the environmental or social impacts of proprietary research. Some research that lacks commercial application could be neglected entirely.

Intellectual property. The increased focus on knowledge and technology as intellectual property, particularly in the biological arena, has led to an enormous increase in patents, licensing and material transfer agreements (MTAs). MTAs provide guidelines for the use of new materials such as genetically modified organisms or plasmic vectors and the ownership of any products or proceeds derived from the materials. Many analysts suggest that these new practices and processes may impede or limit the pace and direction of scientific efforts, restrict scientific communication or undermine an academic scientist's ability to carry out research (Cho 1997).
In 1998, a NIH panel found it problematic that MTAs were setting restrictions under which others could use research tools. Issues raised by NIH concerning MTAs included: their increasing complexity; requirements that ownership of discoveries made with materials must be surrendered; requirements giving the provider the right to preview publications; restrictions on possible collaborative agreements with other companies or universities; and exclusive rights for the provider to decide about patenting discoveries (Campbell et al. 1998).

A recent survey of public plant breeders at 25 U.S. universities found that many scientists had experienced difficulties obtaining genetic stocks from private companies ( $48 \%$ ), and that this had interfered with their research $(45 \%)$, their ability to release new varieties $(28 \%)$ and the training of graduate students (23\%). Several of these problems were traced to MTAs (Price 1999).

Secrecy agreements. Companies supporting university biomedical research often ask scientists to go beyond the standard secrecy requirements needed to obtain patents for products related to their research. In a 1994 study of 210 agricultural, chemical and pharmaceutical business executives, $56 \%$ reported that findings from company-supported university research are kept secret "beyond the time required to file a patent" (Blumenthal et al. 1996). Moreover, while NIH calls for a delay of only 1 to 2 months while an application is filed, $58 \%$ of the companies asked researchers to keep data secret for more than 6 months. Additionally, $30 \%$ of the companies reported that a conflict of interest had arisen "when the academic institution became involved with another company," and $34 \%$ said they had disputes with academic researchers over intellectual property (Blumenthal et al. 1996). While these findings are primarily related to the highly competitive pharmaceutical industry, they raise important issues for agriculture and other sectors.

Corporate gifts. Research-related corporate gifts are also on the rise and often come with similar restrictions. In 


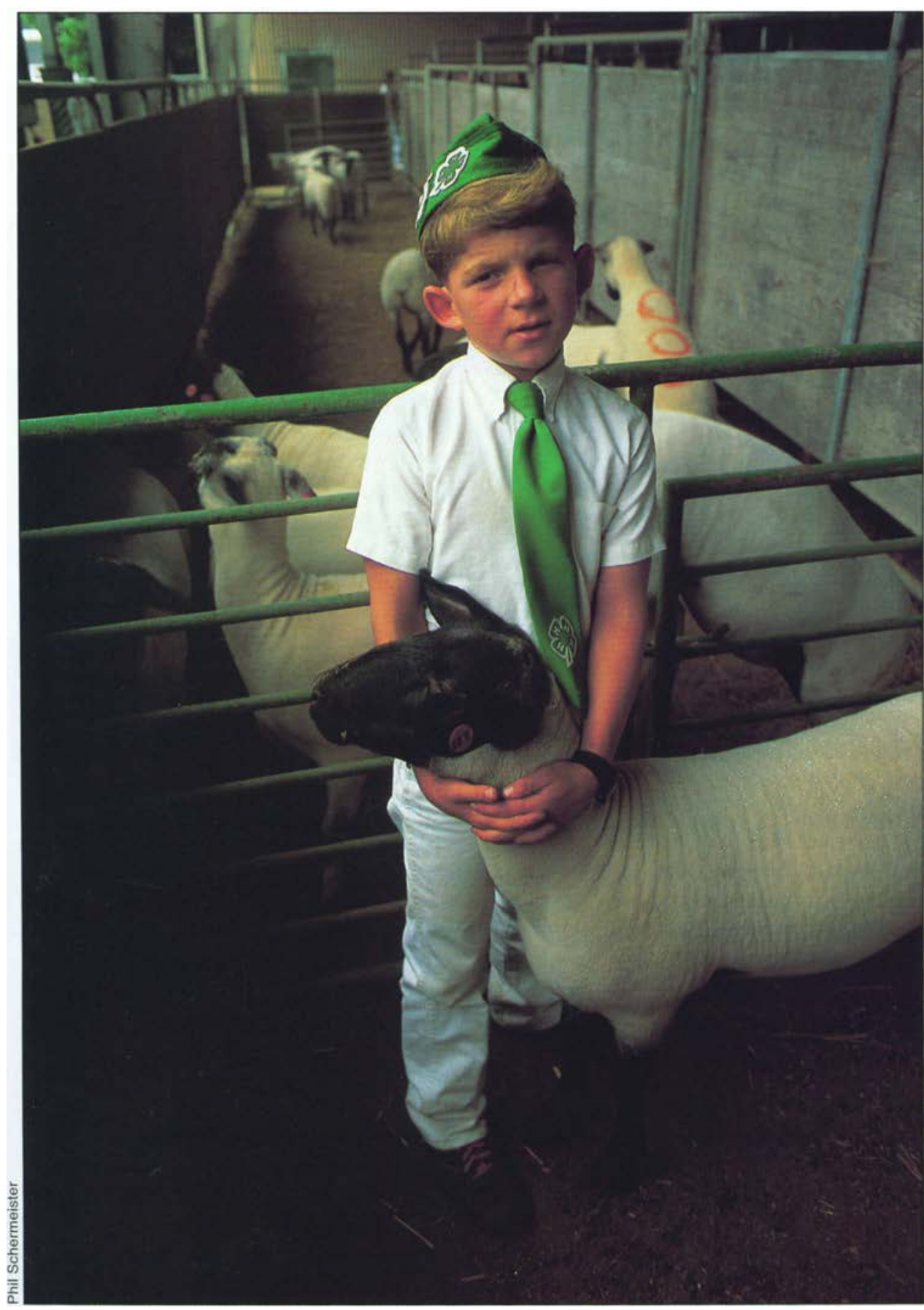

Federal funding for agricultural research and extension has stagnated over the past two decades at about $\$ 825$ million, leading universities to seek out additional funding sources for agricultural programs. A 4-H-er displays his sheep at the Humboldt County fair.

a recent Harvard Medical School study, nearly half ( $43 \%)$ of life scientists at U.S. universities in 1994-1995 $(2,167$ scientists who had received grants from NIH) indicated that they had received at least one researchrelated corporate gift, independent of a grant or contract, during the previous 3 years. Most of these scientists $(66 \%)$ said the gift had been important to their research. Most universities have policies that prohibit specific conditions or "deliverables" as part of the gift arrangement. However, $32 \%$ of the life scientists said the donor had wanted the right to review all publications and had restricted them from sharing the research materials or results with colleagues. One in five gift recipients indicated that the donor expected ownership of all patentable results from research involving the gift (Campbell et al. 1998). Therefore, it is important for universities to not only establish appropriate gift policies, but to monitor gifts and educate faculty regarding their obligations.

Legal disputes. A further impact of the increase in patenting by both the private sector and universities has been an increase in legal confrontations, with lawsuits being filed by various parties involving patent infringement disputes. For example, a bitter patent infringement case between UC and Genentech regarding an engineered human growth hormone was recently settled when Genentech agreed to pay the university $\$ 200$ million (Science, Nov. 26 , 1999). This settlement has provided valuable resources to the institution and the scientists, but it does create an adversarial relationship. It is conceivable that in the future public universities may be suing each other over patent infringement.

Conflicts of interest. Another issue involves potential conflicts of interest and/or scientific misconduct. In interviews, public- and private-sector scientists express concerns about the potentially detrimental effects of restrictive agreements between universities and corporations (Lacy and Busch 1989). These effects include favoritism, unwarranted financial advantages through privileged use of information or technology derived from publicly funded research, and shelving of research of interest to the public but not to the corporation.

Lack of disclosure. Three years ago Tufts University professor Sheldon Krimsky analyzed the industry connections of the authors of nearly 800 scientific papers published in 14 journals in 1997 (Blumenstyk 1998b). In one out of three papers, at least one of the primary authors had a financial interest connected to the research, but most of those circumstances were not disclosed in the journals. Moreover, there often were differences in the findings reported by those with and without industry connection. A researcher at George Washington Medical Center noted that scientists like to think that they are not influenced by their financial ties, "but the pressures may be too subtle for them to realize" (Blumenstyk 1998b). 


\section{Future in focus: Complementary research and strong oversight}

In the early 1990s, Harvard University President Derek Bok warned that the commercialization of universities might be the most severe threat facing higher education. As universities become "more entrepreneurial they appear less and less as charitable institutions seeking truth and serving students and more and more as huge commercial operations that differ from corporations only because there are no shareholders and no dividends," Bok said. He concluded, "It will take very strong leadership to keep the profit motive from gradually eroding the values on which the welfare and reputation of universities ultimately depend" (McMillen 1991).

The future will depend on strong, independent, complementary research efforts by both the public sector and the private sector. Neither will thrive for long if the other is weakened or its goals and integrity eroded. The future will also involve continued expansion of university and industry relationships and new and creative forms of collaboration. For these collaborations to realize the goals and benefits of both sectors, the potential negative consequences will need to continue to be monitored and addressed aggressively with appropriate policies, practices and organizational arrangements.

At the same time, adequate investment for public-sector research will be essential for universities to be a strong and complementary partner. Where the goals of the two sectors overlap, these public/private-sector relationships should grow and be highly beneficial. New growth theorists argue that up to $80 \%$ of all U.S. economic growth over the last 80 years is due to investments in research and development. This has clearly been the case in agriculture. It is likely that the next 50 years of economic and agricultural growth will be even more dependent on both strong public- and private-sector research and development.

UC Davis Chancellor Larry Vanderhoef said: "We value and need ethical, well-crafted, mutually beneficial alliances with industry and we are taking steps now to increase those alli- ances and the many benefits they bring to our faculty, our students and the State of California" (Wright 2000). UC President Atkinson amplified this view when he stated UC would not become a job shop for industry nor compromise the quality, independence nor breadth of its research enterprise.

We need to continue to create meaningful policies, guidelines, and organizational practices to ensure that the goals of both the public and private sectors are enhanced. These policies should define conditions and circumstances where collaborations are encouraged and developed as well as where broader public interest takes precedent over free-market considerations in the generation and dissemination of knowledge. Finally, to achieve a just and democratic society, the escalating commercialization of knowledge must be balanced by diverse and responsive public-sector science and technology.

W.B. Lacy is Vice Provost, University Outreach and International Programs, UC Davis. Portions of this paper will appear in "Generation and commercialization of knowledge: Trends, developments and models for public and private agricultural research and education, "in S. Wolfe $(e d)$, Knowledge Generation and Transfer: Implications for the 21st Century (in press).

\section{References}

Blumenstyk G. 1999. Colleges reaped $\$ 576$ million in licensing royalties in 1998 , survey finds. Chron Higher Ed, 12/10/99:A44

Blumenstyk G. 1998a. Berkeley pact with a Swiss company takes technology transfer to a new level. Chron Higher Ed, 12/11/98:A56.

Blumenstyk G. 1998b. Conflict-of-interest fears rise as universities choose industry support. Chron Higher Ed, 5/22/98:A40-1.

Blumenthal D, Campbell EG, Causino N, Louis KS. 1996. Participation of life-science faculty in research relationships with industry. New Eng J Med 335:1734-9.

Broad WJ. 1999. U.S. back on top in industrial research. NY Times on the Web. www.nytimes.com/library/national/science/ 122899sci-research-money.html. December 1999.

Busch L, Lacy WB, Burkhardt J, Lacy L. 1991. Plants, Power and Profit: Social, Economic, and Ethical Consequences of the New Biotechnologies. Oxford, UK: Basil Blackwell. $275 \mathrm{p}$.

Campbell EG, Louis KS, Blumenthal D. 1998. Looking a gift horse in the mouth: Corporate gifts supporting life-sciences research. JAMA 279(13):995-9.
Cho MK. 1997. University-industry research must get closer scrutiny. Chron Higher Ed, 8/1/97:B4-5.

Cohen WM, Florida R, Randazzese L, Walsh J. 1998. Industry and the academy: Uneasy partners in the cause of technological advance. In: Noll RG (ed.). Challenges to Research Universities. Washington, DC: Brookings Institution Press. p 171-200.

Desruisseaux P. 2000. A gift not of cash, but of opportunity. Chron Higher Ed 3/3/00: A36.

Genetic Engineering News. 1998. Guides to Biotechnology Companies. Larchmont, NY: GEN Publishing Inc. $84 \mathrm{p}$.

Korzumi K, Nelson SD. 1997. An overview of federal budget proposals for R\&D in FY 1998. In: Terch AH, Nelson SD, McEnaney C (eds.). AAAS Science and Technology Policy Yearbook. Washington, DC: AAAS. p 151-65.

Lacy WB, Busch L. 1989. Changing division of labor between the university and industry: The case of agricultural biotechnology. In: Molnar J, Kinnucan $\mathrm{H}$ (eds.). Biotechnology and the New Agricultural Revolution. Boulder, CO: AAAS Symposium Series. p 21-50.

Lee YS. 1998. University-industry collaboration on technology transfer: Views from the Ivory Tower. Policy Studies J 26(1): 69-84.

McMillen L. 1991. Quest for profit may damage basic values of universities,

Harvard's Bok warns. Chron Higher Ed, 4/24/ 91, A1, A31.

Meyer JH. 1995. Transforming the Land Grant College of Agriculture for the TwentyFirst Century. Davis, CA: UC Davis.

Murashige KH. 1997. Patents and biotechnology. In: Terch AH, Nelson SD, McEnaney $\mathrm{C}$ (eds.). AAAS Science and Technology Policy Yearbook. Washington, DC: AAAS. p 283-90.

Nelsen L. 1999. Bridging the two cultures in university/industry research collaborations. Paper presented the annual meeting of American Association for the Advancement of Science. Anaheim, CA.

[NRC] National Research Council. 1996. Colleges of Agriculture at the Land-Grant Universities: Public Service and Public Policy. Washington, DC: National Academy Press. $121 \mathrm{p}$.

NRC. 1994. Investing in the National Research Initiative. Washington, DC: National Academy Press. 143 p.

NRC. 1989. Investing in Research: A Proposal to Strengthen the Agricultural Food and Environmental System. Washington, DC: National Academy Press. $155 \mathrm{p}$.

[NSF] National Science Foundation. 1998. Indicators 1998. Washington, DC.

Pollan M. 1998. Playing god in the garden. NY Times Magazine, Oct. 25:44-51, 623, 82, 92-3.

Press E, Washburn J. 2000. The kept university. Atlantic Monthly (March):39-54.

Price SC. 1999. Public and private plant breeding. Nature Biotech 17(Oct): 835 .

Rausser GC. 1999. Fueling the research engine. California Monthly (April):24-6.

Weaver RD (ed.). 1993. U.S. Agricultural Research Strategic Challenges and Options. Bethesda, MD: Agricultural Research Institute. $380 \mathrm{p}$.

Wright S. 2000. Venturing into new territory. UC Davis Magazine 17(2): 26-31. 